\title{
FUNDAMENTALISME ISLAM: \\ Kajian Fenomena Sosio-Religius
}

\author{
Zulfi Mubarak
}

Dosen Fak. Tartiyah UIIS Malang, Peserta Program Doktor IAIN Sunan Ampel Surabaya

\begin{abstract}
Fundamentalism is inescabaly rooted in a specific Protestant experince whose principle theological premise is that the Bible is the true word of God and should be understood literally. In this regard, it makes no sense to speak of fundamentalist Islam because one of the core element of the creed of all believing Muslim is that the Qur'an is the literal (absolutely true) word of God as revealed ti his Prophet Muhannad through the intermediacy of the angel Gabriel.
\end{abstract}

\section{A. Pendahuluan}

Secara umum, menurut Bassan Tibi bahwa fundamentalisme memiliki beberapa karakter, antara lain: Pertama, fundamentalisme agama mempunyai agenda politisasi agama yang agresif dan dilakukan demi mencapai tujuan-tujuannya; Kedua, fundamentalisme, baik Islam atau yang lain, merupakan bentuk superfisial dari terorisme atau ekstremisme. ${ }^{1}$

Istilah "Fundamentalisme Islam" dan berbagai kajian tentangnya, kini begitu populer karena terkait dengan peristiwa serangan terhadap gedung World Trade 
Center (WTC) di New York dan gedung Pentagon, 11 September 2001 lalu. Padahal seseungguhnya diskursus fundamentalis Islam sudah banyak menjadi perhatian kalangan akademisi, baik di Barat maupun di kalangan Islam sendiri jauh sebelum tragedi itu terjadi. Peristiwa 11 September tersebut, memang menjadikan diskursus fundamentalisme Islam mendapar momentum yang baik untuk disorot kembali karena dampaknya yang sangat luas. Negara-negara yang merasa menjadi sasaran dari fundamentalisme Islam, seperti Amerika dan sekutu-sekutunya terus berkampanye secara preventif untuk memerangi fundamentalisme Islam sebagai bagian dari terorisme. Bagi Amerika dan sekutu-sekutunya memahami fundamentalisme Islam itu sebagai hal yang identik dengan terorisme dan ekstremisme. Jika kampanye mereka adalah war against terrorism, maka itu bisa dipahami juga sebagai war against Islam. Kini semua kekuatan dunia dikerahkan untuk memerangi terorisme. Stasiun TV terbesar di dunia, CNN, misalnya, merasa perlu "war against terrorism" sebagai motornya. ${ }^{2}$

Pertanyaannya, benarkah fundamentalisme Islam itu identik dengan terorisme? Apakah fundamentalisme itu hanya terdapat dalam Islam? Kalau memang ya, bagaimana sebenarnya dasar-dasar pijakan fundamentalisme dibangun dalam Islam? Apakah fundamentalisme dalam Islam itu merupakan fenomena yang tunggal? Benarkah fundamentalisme dalam Islam itu selalu didasari oleh kepentingan agama? Adakah unsur-unsur di luar sentimen-sentimen keagamaan yang melatarbelakangi aksi-aksi mereka? Tulisan ini hendak menjawab pertanyaanpertanyaan sepintas di atas.

Dalam kesempatan ini, penulis mencoba untuk menggunakan analisis wacana terutama yang dikembangkan oleh Michel Foucault. ${ }^{3}$ Yang dimaksud dengan analisis wacana (discourse analysis) di sini adalah seperangkat analisis yang didasarkan kepada diskursus. Definisi diskursus (terjemahan langsung dari istilah discourse) menurut Foucault adalah sekelompok pertanyaan yang memiliki modalitas keberadaan tertentu atau sekelompok pertanyaan sistem formasi yang tunggal. Secara sederhana, diskursus bisa juga didefinisikan sebagai body of thought. Paul Rabinow dan Dreyfus mendefinisikan diskursus sebagai a serious speech act yang bisa saja diomongkan, direkam pada pitakaset, atau ditulis dalam buku-buku. ${ }^{4}$ Dalam analisis diskursus ini, "statement" (pernyataan) mendukung posisi terpenting atau dengan bahasa lain "statement" adalah the atom of discourse. ${ }^{5}$ Namun demikian, menurut Carrette, the idea of statement itu jangan dirancukan dengan 
analisis kalimat (sentence) dan juga analisis bahasa bahasa (linguistic). Menurutnya, simbol bahasa tidak membentuk sebuah "statement", karena "statement" itu lebih merupakan sebuah fungsi yang melintas kesatuan-kesatuan. Karenanya, dengan ini sebuah pertanyaan dalam diskursus juga tidak selalu merupakan sntitas yang tertulis. Lebih lanjut, sebuah diskursus juga tidak harus sebuah tulisan. Analisis diskursus lebh dalam dari hanya sekadar analisis kalimat dan bahasa karena dampak dari analisis diskursus ini bisa jadi ideologi dan juga politik. Sebenamya, apa yang ingin dikemukakan Foucault mengenai "statement" dalam analisis diskursus ini adalah bahwa kemunculan sebuah "statement" itu selalu berada dalam sebuah konteks, tempat dan juga keadaan dari mana sebuah "statement" tersebut berasal. Analisis kalimat dan bahasa tidak sampai kepada analisis yang bersifat politis dan ideologis yakni menguak apa yang menjadi latar dari sebuah kalimat atau bahasa. Sedangkan dengan analisis diskursus ini, Faocault ingin menunjukkan bagaimana ide-ide, obyek-obyek dan konsep-konsep itu dibangun. Diskursus itu sendiri dibangun di atas formasi diskursus yang meliputi empat hal: rezim, keinginan, kekuasaan, dan pengetahuan. Lalu bagaimana analisis diskursus tersebut itu digunakan untuk menganalisa gerakan maupun pemikiran tentang fundamentalisme Islam.

\section{B. Fundamentalisme Islam: Kajian dalam Perspektif Makna}

Dalam perspektif teori analisis diskursus (diskursus analysis) kemunculan sebuah institusi, praktik dan konsep sangat terkait dengan empat hal: will (keinginan), power (kakuasaan), discipline (disiplin) dan regime (pemerintahan). Empat hal ini dikenal dengan istilah formasi diskursif (discursive formations), bangunan yang mendasari adanya sebuah diskursus. Dengan ini, Foucault ingin memberikan kesadaran kepada kita bahwa pengetahuan itu dikontrol, dibatasi dan terkadang dikucilkan. Dia mengilhamkan tentang the politics of all forms of knowledge, semacam politik di balik segala bentuk pengetahuan. Kemunculan fundamentalisme Islam atau fundamentalisme keagamaan yang lainnya sebagai bentuk diskursus (institusi, praktik, dan konsep) dari perspektif teori analisis diskursus tidak bisa dilepaskan dari formasi diskursifyangmendasari sebuah diskursus tersebut terbentuk dan muncul ke permukaan. Empat formasi diskursif dia atas, merujuk ke Foucault, kalau kita amati secara jeli berada di sekitar diskursus fundamentalisme Islam. Artinya, kemunculan fundamentalisme Islam itu sangat erat terkait dengan keinginan 
(will) dari pihak yang mengkonstruksinya baik dari dalam Islam maupun dari luar Islam, kekuasaan (power) yang mengitarinya baik dari dalam Islam maupun dari luar Islam, disiplin yang mengaturnya dan juga rezim yang sedang berkuasa, keduanya juga baik dari dalam maupun dari luar Islam. Meskipun di sana ada unsur dalam maupun luar Islam, kenyataannya menunjukkan bahwa pemegang empat hal tersebut saat ini dalam konteks global adalah Barat. Meskipun demikian, penggunaan analisis diskursus oleh kita biasa juga digunakan untuk melihat sebaliknya bahwa fundamentalisme Islam bisa dianggap sebagai cara untuk melakukan kritik terhadap Barat. Barat sebagai pihak yang memproduksi diskursus fundamentalisme Islam ini sudah barang tentu memiliki kepentingan-kepentingan tertentu di balik itu semua. Sebagaimana kita tahu kemunculan diskursus fundamentalisme keagamaan justru yang pertama kali muncul itu di kalangan Kristen. Sosiolog muslim Ilyas Ba-Yunus, the State University of New York College at Cortland, dalam sebuah artikelnya, "The Myth of Islamic Fundamentalisme," menjelaskan pemakaian diskursus fundamentalisme untuk pertama kali muncul dalam sebuah konferesi mengenai Bible 1878 yang diselenggarakan di Nigara Falls New York. Konferensi ini dihadiri terutama oleh kalangan pemimpin Baptis, Presbyterian, dan aktivis gereja. Konferensi ini menghasilkan 9 prinsip fundamental. Para penandatangan deklarasi tersebut menamakan diri mereka sebagai kaum fundamentalis dan mereka menyebut para penentangnya dengan kaum heretik.

Karenanya, sangat wajar apabila secara terminologis, fundamentalisme Islam sampai kini masih sering menjadi perdebatan baik oleh kalangan dalam Islam sendiri maupun oleh kalangan di luar Islam. Salah satu hal yang diperdebatkan adalah mengenai penggunaan istilah fundamentalisme itu sendiri dalam diskursus Islam. Salah satu hal yang diperdebatkan adalah mengenai penggunaan istilah fundamentalisme itu sendiri dalam diskursus Islam. Apakah istilah ini cocok untuk menamai fenomena gerakan radikal dalam Islam, ataukah tidak? Sheila McDonough misalnya lebih memilih istilah fundamentalisme ketika ia menjelaskan tentang fenomena pemikiran radikalisme Islam yang diperkenalkan oleh Maulana Maududi.?

Menurut McDonough, istilah ini merupakan perkiraan yang paling dekat dengan fenomena yang dipertunjukkan oleh Maududi yang menghendaki revitalisasi nilai-nilai Islam dalam kehidupan dunia. ${ }^{8}$ Berbeda dengan Sheila McDonough, Seyyed Vali Reza Nasr lebih suka menggunakan istilah revivalisme. Menurutnya, 
istilah ini menyimpan makna yang lebih dalam, tidak hanya menggambarkan fenomena gerakan penafsiran agama yang didasarkan kepada tulisan (scripture), akan tetapi merupakan gerakan yang sangat berkaitan dengan persoalan-persoalan politik ummat (communal politics), pembentukan identitas (identity formation), persoalan kekuasaan dalam masyarakat yang plural serta mengenai nasionalisme. ${ }^{9}$ Jadi istilah revivalisme ini lebih luas jangkauannya karena pada kenyataannya kemunculan gerakan Islam radikal di negara-negara Islam di Timur Tengah maupun di Asia memang tidak semata-mata didorong oleh keinginan mereka untuk menerapkan makna literal dalam teks-teks suci dalam kehidupan nnyata, dan tidak hanya pula sekedar tandingan terhadap cengkeraman Barat, akan tetapi lebih filosofis.

Sebagaimana Sayyid Vali Reza Nasr, John L. Esposito misalnya lebih memilih menggunakan istilah revivalisme atau aktivisme Islam karena istilah fundamentalisme terbebani oleh asumsi-asumsi kristiani dan pelabelan oleh dunia Barat serta mengandung ancaman yang bersifat monolitk. Menurut Esposito, dua istilah yang diusulkan, Islamic revivalism dan Islamic activism, lebih ringan bebannya selain juga memiliki akar yang kuat dalam tradisi reformasi dan aktivisme sosial dalam Islam (Esposito, "Islamic Fundamentalism", Encyclopedia Britanica, 1996). Apa yang diusulkan oleh Esposito di atas lebih merupakan sebuah upaya untuk melihat sisi sernantis fundamentalisme Islam yang memang seringkali dipahami secara salahkaprah oleh kalangan Barat, namun demikian Islanic revivalism atau Islamic activism bukan istilah yang tanpa beban pula. Kesadaran bahwa istilah fundamentalisme lslam itu tidak netral juga dikemukakan oleh Johan Blank dalam artikel pendeknya "Modernity dan Islamic fundamentalism", yang merupakan kesimpulan dari bukunya Mullahs on the Mainframe, diterbitkan oleh the University of Chicago Press. Dia menyadari bahwa di Barat memang terjadi semacam prasangka buruk terhadap Islam termasuk dengan penggunaan istilah fundamentalisme sendiri untuk menunjuk sekelompok umat Islam secara literalis dan beraksi secara ekstrim.

Istilah lain yang dekat dengan fundamentalisme adalah puritanisme. Istilah ini merujuk kepada kelompok Wahhabi di Arab Saudi. Kelompok puritan ini menawarkan seperangkat referensi tekstual yang mendukung orientasi teologis yang intoleran dan mengucilkankelompok yang berlainan dengan mereka. Kelompok yang sering menyitir ayat-ayat al-Quran dengan cara melakukan isolasi teks al- 
Quran dari sisi historis dan sosiologisnya. Karenanya, tafsir-tafsir yang dihasilkannyapun memiliki kecenderungan tinggi untuk melakukan pengucilan. Muslim bagi kelompok ini adalah pewaris dari the divine truth. Keberadaan Yahudi dan Nasrani bisa ditolerir namun mereka tidak bisa dijadikan sebagai teman. Kalangan Yahudi dan Nasrani bagi mereka harus tetap dipaksa untuk mengetahui supremasi muslim dengan bayaran pajak yang penuh untuk mereka.

Sedangkan al-'Ashmawy, sebagaimana para penulis yang lain pada hari ini, dia tidak menggunakan istilah " fundamentalism" untuk menguraikan apa yang ia pikir menjadi lebih baik dipahami, seperti "extremism" (pendirian yang radikal). Pokok/dasar Islam ( ushul al-din)- al-Quran dan al-Sunnah dan Rukun Islam tidaklah diperdebatkan. Tidak seorangpun, baik konservatif ataupun liberal, yang mempertanyakan pokok keimanan; berbagai hal penafsiran dari sumber dan aplikasinya dari gagasan inilah yang di dalam masyarakat lau menjadi isu. ${ }^{10}$

Emmanuel Sivan" lebih memilih menggunakan istilah Islam radikal (radical Islam) untuk menggambarkan kecenderungan yang sama. Ia melihat terjadi proses pembangkitan ide-ide Islam abad pertengahan sebagai jalan menuju dunia modern. Contoh yang bisa diambil untuk mengekspresikan bentuk gerakan Islam radikal yang dimaksud oleh Sivan adalah gerakan Islam yang diprakarsai oleh organısası keagamaan seperti lkhwanul Muslimin di Mesir.

\section{Akar Fundamentalisme dalam Islam}

Menurut Mahmud Amin al-Alim yang dikutip Abdurrahman Kasdi, bahwa istilah "fundamentalisme", secara etimologi berasal dari kata "fundamen" yang berarti dasar. Sedangkan secara terminologi, fundamentalisme adalah aliran pemikiran keagamaan yang cenderung menafsirkan teks-teks keagamaan secara kaku (rigid) dan literalis (textual). ${ }^{12}$

Pendapat-pendapat di atas, pada dasamya adalah upaya-upaya pemaknaan atau pembuatan diskursus, baik oleh kalangan Islam sendiri maupun oleh kalangan peneliti Islam Barat (Islamisis) dalam usaha mereka untuk menbangun mengenai fenomena Islam garis keras (fundamentalist). Hasil konstruksi mereka antara lain adalah fundamentalisme atau sebutan-sebutan yang lain, adalah mewujud di kalangan masyarakat muslim dan memiliki akar dalam teologi lslam. Sudah barang 
tentu, dalam mewujudkan diskursus ini (discursive practices), mereka tidak akan terlepas dari formasi yang mendukung kemunculan diskursus. Apakah ada kemiripan (resemblames) yang muncul antara fenomena fundamentalisme dan kecenderungan yang ada dalam sejarah Islam?

Dengan kata lain, pembicaraan dalam bagian ini adalah pembicaraan mengenai asal-usul, mengenai sejarah keterkaitan antara satu ide pernikiran yang muncul pada masa sekarang dengan pemikiran yang muncul pada masa yang sudah berjalan jauh sebelum kita. Dalam konteks demikian, Michel Foucault sebenarnya menawarkan sebuah teori yang cukup menarik untuk melihat apakah sebuah ide masa lalu itu memiliki atau selalu mengait dengan ide masa sekarang. Meskipun teori ini masih menjadi bagian dari teori besar analisis diskursus, namun Foucault memberi nama lain yakni teori Arkeologi ${ }^{13}$ Pengetahuan.

Dalam Arkeologi Pengetahuan, Foucault memperkenalkan teori sejarah baru yang tidak konvesional mengenai pemaknaan. Arkeologi ini bertugas untuk melakukan eksplorasi bagaimana proses historis obyek-obyek pengetahuan yang dibangun. Arkeologi melihat kondisi-kondisi yang memungkinkan bagi kelahiran sebuah idea. Termasuk dalam pandangan arkeologi ini mempertanyakan kesatuan tradisional mengenai oeuvre, tulisan, dan pengarang, dengan cara melakukan pengujian terhadap kondisi-kondisi dalam mana oeuvre tersebut diproduksi dan diciptakan. ${ }^{14}$ Dalam esei ini, Foucault menyatakan bahwa fungsi pengarang telah mati. Maksudnya ialah pengarang tidak lagi menempati posisi pusat untuk pemaknaan sebuah teks yang dikarang sebagaimana pandangan dunia kepengarangan tradisional. Jika ditarik dalam konteks fundamentalisme Islam maka fungsi umat Islam sebagai pencipta gerakan tersebut tidak lagi menjadi faktor utama untuk dikejar dan harus bertanggung jawab sebab kenyataannya kepengarangan fundamentalisme Islam sudah menjadi urusan banyak pihak.

Pernyataan Foucault ${ }^{15}$ memberikan kesadaran pada kita akan kritisisme tentang keterpenggalan. Kritisismeketerpenggalan ini sangat berguna untuk melihat bahwa gerakan Islam fundamentalis bukan merupakan gerakan totalitas sejarah. Kalau kita baca sumber-sumber tentang fundamentalisme maka selalu ada upaya untuk mengaitkan dengan ide-ide Islam awal yang memungkinkan bisa dimaknainya sebagai akar fundamentalisme Islam.

Dalam Islam, memang dikenal fenomena fundamentalisme keagamaan. Namun, fenomena fundamentalisme agama ini dipahami secara berbeda-beda oleh 
pelbagai kalangan intelektual Islam. Muhammad Sa'id al-Asymawi, misalnya, membedakan antara "activist political fundamentalism" dan "rationalist spiritualist fundamentalism. "Istilah pertama merujuk kepada sekelompok Muslim yang memperjuangkan Islam sebagai kekuatan politik. Sedangkan istilah yang berikutnya lebih merujuk kepada sekelompok Muslim yang menginginkan kembali kepada ajaran $\mathrm{Al}-\mathrm{Qur}$ 'an dan tradisi yang sebagaimana dipraktikkan oleh generasi Muslim pertama. ${ }^{16}$ Dari pemaknaan yang diberikan oleh Al-Asymawi di atas maka pembicaraan tentang akar fundamentalisme Islam sebenarnya memiliki dua kemungkinan: Pertama, akar fundamentalisme adalah merujuk kepada gerakan yang memperjuangkan Islam sebagai entitas politik dan ini bisa merujuk kepada kelompok Khawarij yang pada saat itu memang menghendaki hukum sebagai landasan politik. Kedua, akar fundamentalisme dalam Islam adalah generasi awal Islam yakni kehidupan Nabi dan para sahabat, atau dalam bahasa lain adalah kehidupan generasi salaf al-shalih dan ini mirip dengan puritanisme yang positif. Dengan kata lain, akar fundamentalisme Islam adalah bentuk pelaksanaan agama yang berpegang kepada prinsip-prinsip dasar Islam madzab salaf. Pelaksanaan keagamaan masa salaf adalah pelaksanaan keagamaan yang sederhana karena pada masa itu praktik keagamaan masih sepenuhnya merujuk kepada Nabi, Sahabat, dan Tabi'in.

Mohammad Mohaddessin yang menulis buku berjudul Islamic: Fundamentalism, The New Global Threat menjelaskan bahwa sejarah fundamentalisme Islam khususnya berkenaan dengan peristiwa Revolusi Iran 1978/ 1979 memang bisa ditemukan akarnya dalam Islam. Hal yang ia sebutkan misalnya adalah fanatisme keagamaan, di samping juga memperkenalkan kebebasan dalam keagamaan. Khawarij menurutnya kelompok umat Islam pertama yang memiliki kecenderungan dogmatisme yang sangat kuat. Semboyan mereka adalah "la hukma illa Allah" (tidak ada hukum kecuali hukum Allah). Dari kelompok inilah disinyalir pembunuh Ali ra pada $661 \mathrm{H}$ berasal. Kelompok Khawarij adalah kelompok yang pertama kali yang mendeklarasikan bahwa Islam dan Al-Qur'an sebagai ideologi resmi, mereka menentang interpretasi Al-Qur'an yang dinamik yang dipelopori dan disimbolkan oleh Ali. ${ }^{17}$ Dalam satu contoh penafsiran mereka, antara lain, adalah ketika menafsirkan tentang amar ma'ruf nahi munkar dengan mencari kebenaran dengan pedang. Namun, pada masa sekarang, Khawarij tidak menjadi akar sejarah yang kokoh sebagai rujukan gerakan fundannetalisme masa sekarang. 
Bahkan secara ekstrim bisa dikatakan kelompok fundamentalisme Islam sekarang tidak akan mau diidentikkan sebagai neo-khawarij sebab identifikasi yang demikian ini berarti menjerumuskan meskipun jargon-jargon yang dikembangkan oleh kelompok fundamentalisme modern sama dengan jargon-jargon yang dikembangkan oleh kaum Khawarij. Namun, sekali lagi, Khawarij adalah identik dengan kaum pemberontak dan oleh sebagian kelompok Sunni bahkan mereka dianggap sebagai telah keluar dari prinsip-prinsip Islam. Memang keturunan Khawarij masih tersisa di wilayah Oman dan Aljazair namun mereka bukan lagi seperti generasi awal mereka namun jauh lebih moderat.

Mengikuti cara pandang Michel Foucault mengenai "the discontinuity of history", ${ }^{18}$ maka fundamentalisme Islam yang muncul pada masa awal itu bisa jadi tidak memiliki kaitan dengan fundamentalisme Islam masa kini/makna (idea) yang dibangun oleh fundamentalisme sekarang hidup dalam ruang lingkup struktur ajaran sekarang (episteme). Sedangkan sebuah struktur ajaran itu juga dibentuk oleh kebutuhan-kebutuhan sekarang (bahasa sekarang). Dengan ide ini, Foucault hanya ingin mengatakan bahwa pengetahuan (idea) itu dibangun dalam periode historis yang berbeda-beda.

Namun demikian, fundamentalisme Islam secara garis besar bisa ditarik ke dalam dua kelompok, yakni fundamentalisme Islam yang merujuk kepada model Wahhabisme (Sunni) dan fundamentalisme Islam yang merujuk kepada model Syi' ah (Revolusi Iran). Model Sunni Wahhabi adalah gerakan fundamentalisme Islam yang terinspirasikan oleh gerakan puritanisme Wahhabi, sedangkan model Syi'ah ini maksudnya adalah gerakan fundamentalisme Islam yang terinspirasikan oleh keberhasilan Revolusi Iran. Kedua model ini akan diterangkan sebagai berikut. ${ }^{19}$

\section{Model-model Fundamentalisme Islam}

\section{Model Salaf}

Banyak kalangan yang menyebutkan bahwa gerakan salafi merupakan akar (inspirasi) bagi kemunculan gerakan fundamentalisme Islam pada saat sekarang. Kaum salafi adalah gerakan yang menyerukan kembali kepada tradisi salaf (generasi awal) dari dunia Islam. Beberapa ahli menghitung periode salaf adalah 
rentang 400 tahun pertama dari masa Nabi Muhammad Masuk dalam kategori ulama salaf adalah Abu Hanifah, Malik, Syafi'i, dan Ahmad bin Hambal. Berdacarkan pendapat ini, siapa saja yang meninggal setelah masa ini, maka mereka masuk dalam periode khalaf. Istilah salafi kemudian dibekukan dan kini dibangkitkan lagi untuk digunakan terutama sebagai slogan dan gerakan yang dilakukan oleh para pengikut Muhammad Abduh yang juga murid seorang aktivis dan ideologi Islam Muhammad Jamaluddin al-Afghani. Dasar klaim dari gerakan ini adalah agama sudah tidak secara benar dipahami oleh pengikutnya sebagaimana pada masa Nabi. Gerakan salafi ini menyerukan kembali kepada ortodoksi syari'ah yang akan memumikan Islam dari unwarranted accretions, kriteria sesuai dengan AlQur'an dan hadits.

Abdul Hadi Abdul Rahman dalam Sulthah al-Nash, Qira'ah fi Taudzif al-Nash al-Dini menyatakan bahwa gerakan salaf ini dihidupkan pertama kali oleh Ibn Hambal pada abad IV H, dan kemudian dipertegas lagi oleh Ibn Taimiyyah abad VII H dan kemudian semakin dibakukan oleh Muhammad bin Abdul Wahhab pada abad XII H di Jazirah Arab. Penisbahan pada yang terakhir inilah kemudian memunculkan gerakan Wahhabisme. Abdul Hadi Abdul Rahman menggambarkan ideologi keagamaan kaum salaf sebagai berikut: "Akjdah itu tidak bisa dijadikan pegangan kecuali dari teks, adapun akal itu menyesatkan, sistem penalaran rasional yang berdasarkan ilmu Manhtiq (logika) yang telah digunakan oleh kalangan filosof dan ahli kalam itu tidak pernah dikenal pada masa sahabat atau generasi setelah sahabat (tabi in). ${ }^{20}$ Menurut Ibn Taimiyah apa yang telah dikemukakan Al-Qur'an dan mendapat penjelasan dari Sunnah itu harus diterima. Baginya, akal tidak memiliki kemampuan untuk mentakwilkan, menafsirkan dan men-takhrif Al-Qur'an kecuali itu ada indikasi dengan ungkapannya. ${ }^{21}$ Gambaran yang diberikan oleh Abdul Hadi Abdul Rahman mendekatkan kenyataan akan keberakaran gerakan fundamentalisme Islam terhadap salafisme.

Atas cara tafsir dan baca terhadap teks yang dimiliki oleh model salaf atau Wahhabisme di atas, menurut Khalid Abou el-Fadl, menyebabkan kelompok ini sering menyemaikan the theology of intolerance sebagai lawan dari the theology of tolerance. The theology of intolerance ini sebenamya tidak hanya menjadi milik Wahhabi saja, akan tetapi juga menjadi milik dari kelompok-kelompok Islam puritan yang lain. Ada beberapa hal krusial yang dikemukakan oleh gerakan salafi ini sebagaimana yang digambarkan oleh Khalid Abou el-Fadl yang memiliki 
kemiripan dengan prinsip-prinsip yang diperjuangkan oleh gerakan fundamentalisme Islam antara lain adalah cara penafasiran teologis mereka yang tidak toleran dan cenderung mengucilkan kelompok non-Islam. Dalam menafsirkan mengenai relasi muslim dan non-muslim, kelompok ini juga cendenmg mengutip ayat-ayat Al-Qur'an yang menurut mereka memerintahkan peperangan terhadap non-muslim. Menurut Khalid Wahhabi itu mengklaim diri mereka sebagai kelompok yang berpegang kepada fidelity of the teks dalam Islam. Jalan yang mereka tempuh dianggap sebagai jalan kebenaran bagi mereka. Hal yang patut diingat di sini adalah tidak semua kelompok Wahhabisme mau dikatakan sebagai pengikut dari tokoh tertentu termasuk Muhammad bin Abdul Wahhab. Namun demikian, yang kelas Wahhabisme ini bisa dimasukkan ke dalam kelompok salaf.

Di sinilah sebenarnya, kita bisa melihat perbedaan antara salafisme yang berakar pada Muhammad bin Abdul Wahhab dan salafisme yng berakar kepada Muhammad Abduh dan Jamaluddin al-Afghani dari awal pembentukannya memliki konsep yang jelas bahwa Islam harus menjawab tantangan modemitas. Untuk menjawab tantangan modernitas ini, konsep teologi yang dikembangkan oleh mereka adalah teologi liberal. Caranya adalah kembali kepada Al-Qur'an dan tradisi Nabi dan terikat dalam de novo of interpretation of teks.

Namun, pada tahun 1970-an Wahhabisme telah sukses melakukan proses transformasi secara keseluruhan model-model salafisme yang puritan, konservatif dan literalis. Saudi Arabia sebagai rezim pemasok ide ini mengalami kejayaan di mana kenaikan harga minyak yang sangat tajam pada tahun 1975 menjadikan kerajaan ini menjadi rezim yang mengatur diskursus ini menjadi diskursus bagi negara-negara Islam yang secara ekonomi mungkin mendapat bantuan dari rezim penyebar. Pola yang demikian menjadi nampak jelas kalau dilihat dari perspektif teori terelasi kuasa dan pengetahuan Foucault di atas. Kebangkitan sebuah diskursus pengetahuan (konsep, ide dan gerakan) tidak lepas dari kuasa. Kuasa ini mengejawantah dalam supremasi Saudi Arabia sebagai negara berpenganh untuk dunia Islam. Di Indonesia sendiri penyaluran ide Wahhabisme ini disebarkan melalui LIPIA dengan cara menyediakan pendidikan gratis dan beasiswa bagi kalangan Islam. Hasil dari pendidikan ini misalnya bisa kita lihat dengan kemunculan partaipartai politik atau organisasi-organisasi keagamaan Islam yang ide dan gerakannya memiliki kesamaan dengan Wahhabisme. 


\section{Model Syiah}

Akar fundamentalisme Islam yang kedua biasa dijadikan perbincangan adalah keberhasilan Revolusi Iran 1979. Apabila kita berbicara mengenai Revolusi Iran, maka kita akan selalu mengaitkan dengan keberhasilan ideologi Syi' ah dan Syi'ah modem itu seringkali dikaitkan dengan Imam Khomeini. Dalam bayangan kita bahwa Imam Khomeini merupakan representasi dari ke-Syi'ah-an. Pandangan demikian, pada dasarnya, sangat wajar karena keberhasilan figur Khomeini memang sangat penting. Akibatnya, ketika Revolusi Iran atau Khomeini diklaim sebagai representasi dari fundamentalisme Islam, maka semua Syi' ah menjadi terkenal padahal di dalam Syi'ah tidak hanya ada Imam Khomeini, namun juga ada tokoh-tokoh yang lain. Bagian ini kan melihat dinamika pergerakan selama menjelang Revolusi Iran antara kelompok Syi'ah yang cenderung fundamentalis dan kelompok Syi'ah yang cenderung modernis. Pembicaraan ini sangat penting agar terjadi kejelasan mana akar-akar Syi'ah yang mendukung fundamentalisme Islam dan yang menolaknya.

Ketika menjelang terjadinya Revolusi lran pada tahun 1979, peta gerakan politik di Iran yang bertujuan untuk menjatuhkan Syah Iran terbagi ke dalam tiga kelompok: Nasionalis, Marxis dan Fundamentalis. Kelompok Nasionalis dengan the National Front (Front Nasional) mewakili kelompok oposisi sekular. Namun sepeninggal pemimpin mereka, Mossadeq, Front nasional diambil oleh kalangan politisi yang secara total keluar dari kebutuhan-kebutuhan masyarakat Iran di samping gerakannya sangat pasif. Mereka tidak memiliki agenda politik yang jelas. Satu modal yang masih ditinggalkan Mossadeq adalah popularitasnya di tingkat massa. Kelompok kedua adalah kelompok Marxis. Kelompok inipun ternyata tidak satu, sebagian mereka ada yang mengikuti garis politik Party Tudeh yang pro Moscow, tapi ada juga yang mengikuti garis politik partai-partai komunis di kawasan Albania. Namun, kelompok ini tidak mampu menembus massa Iran. Marxisme mungkin hanya populer di kalangan dunia kampus dan intelektual. Kelompok ketiga adalah kelompok fundamamentalisme Islam yang dikuasai oleh kelompok Feda 'in Islam, group yang fanatik dan dogmatik pada tahun 1960-an. Pada tahun 1963-an, pengucilan Khomeini ke Iraq telah menjadi permulaan bagi dua untuk diakui sebagai pemimpin kelompok oposisi dari kalangan fundamentalisme Islam. Hal ini mudah mendapatkan simpati karena tujuan yang kuat dari Khomeini ini adalah melakukan land reforms dan mengurangi penderitaan perempuan. Kelompok Mujahidin dengan 
diprakarsai oleh Hanifnejad diharapkan bergabung dengan kelompok oposisi Front Nasional atau kelompok Syi' ah pro-Khomeini. Namun Hanifnejad memilih untuk melakukan penelitian tentang pelbagai aspek ajaran Islam selama 6 tahun yang mana penelitian tersebut bertujuan untuk membedakan mana Islam yang asli berasal dari Rasul dan mana Islam yang diselewengkan oleh kalangan fanatis. Pada titik inilah sebenarnya inti dari perlawanan kelompok Hanifnejad terhadap fundamentalisme Islam. Kelompok Mujahidin ini mengingatkan tentang bahaya fundamentalisme dan berusaha keras untuk membedakan dengan Islam reaksinonisme. Mereka memproduksi karangan-karangan mengenai persoalanpersoalan eksistensi, sejarah, manusia dan ekonomi. Bahkan mereka menghadirkan tafsir mereka sendiri atas Al-Qur'an dan Nahj al-Balaghah. Massoud Rajavi adalah tokoh yang patut diperhitungkan untuk hal ini.

Namun Syah menangkap Muhammad Hanifnejad dan juga Rajavi. Pada tahun 1972, Hanifnejad dieksekusi, namun Rajavi tidak jadi dihukum mati karena tekanan-tekanan dunia internasional dan juga usaha yag dilakukan oleh saudara tuanya Rajavi kemudian mengambil alih kepemimpinan Hanifnejad. Hukuman mati atas Muhammad Hanifnejad mengundang banyak simpati, bahkan dari kalangan fundamentalisme Islam seperti Rafsanjani. Rahaavi dari balik penjara mencoba untuk merevitalisasi prganisasi Mujahidin dengan menfokuskan pada program pembedaan Islam demokratis dari pelbagai macam bentuk Islam yang ideologis lainnya. Fundamentalisme manjadi ancaman yang nyata bagi perjuangan kelompok Syi'ah Mujahidin. Namun gerakan fundamentalisme Islam yang diprakarsai Khomaeni mendapatkan keuntungan atas penangkapan Rajavi untuk memegang tampuk perlawanan atas Syah. Akhimya, kelompok Khomeini inilah yang memenangkan pertarungan. Oleh kalangan fundamentalisme Islam internasional, keberhasilan Khomeini dijadikan sebagai salah satu model bagi gerakan ini. Namun, patut diingat bahwa sebagai model itu tidak berarti semua bentuk fundamentalisme Islam yang menjadi tuntunannya, kalau memang, memiliki kesamaan-kesamaam dengan yang asalnya.

\section{E. Fundamentalisme Islam di Indonesia}

Bagaimana dengan gerakan fundamentalisme Islam di Indonesia. Model manakah yang menjadi rujukan mereka, apakah mereka meniru model Wahhabi 
Sunni ataukah Syi'ah-Khomeini. Atau mungkin mereka melakukan kreasi sendiri. Kalau kita lihat akar historis fundamentalisme dalam Islam di atas, dengan menggunakan pendekatan keterpenggalan sejarahnya Foucault, bisa jadi gerakan fundamentalisme di Indonesia tidak memiliki keterkaitan dengan gerakan fundamentalisme di luar. Namun, ide keterpenggalan sejarah yang dikemukakan oleh Foucault ini tidak berarti meniadakan adanya relasi antar-diskursus. Relasi antar-diskursus tetap saja bisa terjadi, namun relasi tersebut tidak dalam bentuk relasi sederhana dalam bentuk sebab-akibat, dalam bentuk determinasi yang memutar, dalam bentuk antagonisme, atau relasi dalam ekspresi di antara peristiwaperistiwa yang terjadi (dated events).

Kemunculan fundamentalisme Islam di Indonesia bisa jadi memang memiliki keterkaitan historis dengan fundamentalisme Islam di wilayah lain atau dengan masa lalu, namun bisa jadi keterkaitannya bukan pada level bahwa FPI (Front Pembela Islam), Majlis Mujahidin Indonesia, Laskar Jihad, Hizbut Tahrir atau lain sebagainya, merupakan akibat yang determinan dari model fundamentalisme Wahhabi Sunni atau dari model fundamentalisme model Syi'ah-Khomeini. Kalau mungkin ada keterkaitan maka keterkaitannya adalah kemungkinan-kemungkinan. Mengapa demikian? Bisa diilustrasikan apabila kita anggap bahwa fundamentalisme Islam Sunni atau Syi' ah itu sebagai sebuah seri kebenaran sejarah, di dalam sebuah seri kebenaran sejarah tersebut tentunya terdapat eleman-elemen yang didefinisikan sebagai pendukung seri kebenaran sejarah tersebut. Ambil contoh, FPI, Hizbut Tahrir, dan kelompok-kelompok Islam fundamentalisme. Maka, persoalannya di sini adalah bagaimana kita bisa membangun seri kebenaran tersebut; pertanyaanpertanyaananya adalah misalnya bagaimana mendefinisikan bahwa satu elemen dengan elemen yang lain saling memiliki keterkaitan, satu elemen dengan elemen yang lain bisa saling membatasi untuk membentuk kebenaran, dan lain sebagainya, yang akhirnya nanti akan membuat kesimpulan bahwa fundamentalisme Islam di Indonesia bagian dari jaringan fundamentalisme Islam internasional.

Salah satu fungsi analisis diskursus untuk melihat fundamentalisme Islam adalah bahwa ia memberikan ketidakmutlakan, heterogenitas, kemungkinankemungkinan, dan keterbukaan-keterbukaan. ${ }^{22}$ 


\section{F. Fundamentalis dan Kekerasan Beragama}

Pada bagian ini, saya sengaja untuk mengutip dari hasil book review dari seorang Sosiolog Agama yaitu Prof. Dr. Imam Suprayogo, karena hal itu penting dan berkaitan dengan upaya memahami sebuah fenomena fundarnentalisme ini. ${ }^{23}$

Buku berjudul Fundamentalisme and The State yang diedit oleh Martin E. Marty dan R Scott Appleby ini merupakan kumpulan karangan yang ditulis oleh dua puluh tiga orang ahli. Mereka itu terdiri dari para ahli politik, hukum, sosiologi antropologi budaya, para ahli sejarah agama dan para ekonomi. Beberapa diantara, mereka memiliki simpati yang besar pada faham fundamentalisme, namum mereka tidak mengklaim diri sebagai pengikut faham tersebut. Aneka ragam latar belakang keahlian para penulis ini menampakkan sudut pandang yang diambil dalam melihat tema pokok buku ini, yaitu dari sudut politik, ekonomi dan militansinya.

Tulisan-tulisan yang digarap tahun 1991 dan dipublikasikan pada tahun 1993 ini adalah tepat disebut sebagai buku yang sangat aktual hingga menarik untuk dibaca. Runtuhnya Komunis di Eropa Barat dan tercabiknya ideologi Marxiz di Uni Soviet pada awal tahun 1990-an memunculkan spekulasi dari para pengamat politik tentang: Siapakah musuh baru yang bakal dihadapi? Siapakah yang bakal menggantikan kedudukan komunis yang dianggap musuh bangsa Amerika? Kekuatan politik, ekonomi dan ideologi apa yang akan menjadi penghalang upaya menegakkan demokrasi liberal di negara-negara barat menuju pembangunan dunia secara global pada masa-masa yang akan datang? Atas dasar pertanyaanpertanyaan itu semua maka fundamentalisme agama tampaknya tepat dijadikan sebagai jawabannya. Selanjutnya, buku ini memuat pembahasan-pembahasan dan evaluasi di seputar cara-cara dan upaya kaum fundamentalis yang ikut mewarnai dan mempengaruhi perkembangan di bidang politik, hukum, konstitusi dan ekonomi selama 25 tahun terakhir ini sehingga selayaknyalah bilamana dikatakan berada pada waktu yang tepat kehadirannya.

Umumnya penulis memandang bahwa faham fundamentalis adalah sebagai gerakan yang berjuang untuk menegakkam kembali norma-norma dan keyakinan agama tradisional dalam tatanan kehidupan bernnasyarakat yang dianggap telah menyimpang karena faham sekulerisme. Faham fundamentalis bisa lahir dari semua agama dan di mana saja. Karena itu dikenal istilah fundamentalis Islam, Hindu, Budha, Khatolik, Protestan dan juga Yahudi. Begitu pula bisa lahir dimana saja, 
baik di negara-negara timur maupun barat seperti Amerika maupun Eropa. Suatu kelompok disebut kaum fundamentalis jika kelompok tersebut mampu memegang prinsip secara agresif sehingga kadangkala melakukan aktifitas yang dianggap melanggar Undang-undang negara dimana mereka tinggal. Dengan mengatasnamakan hukum yang suci (Hukum Tuhan) kelompok-kelompok fundamentalis ini melakukan aksi kekerasan. Meskipun mereka memiliki surnbersumber ajaran yang berbeda, doktrin dan juga kelembagaan yang berlainan akan tetapi mempunyai tujuan yang intinya sama, yaitu ingin menciptakan kehidupan masyarakat yang sejahtera berdasarkan atas hukum Tuhan.

Beberapa tulisan yang disajikan dalam buku ini dirangkum dalam tiga tema besar, yaitu yang berkaitan dengan politik, restrukturisasi ekonomi dan hal-hal yang berkaitan dengan militansi. Bahasan yang berkaitan dengan politik diberi porsi yang cukup besar. Ada sebelas tulisan yang membahas tentang ini. Disebutkan bahwa hubungan antara faham fundamentalis dan politik bersifat sangat komplek mengingat adanya perbedaan-perbedaan bentuk pemerintah, hubungan internasional, pengelolaan ekonomi, adat istiadat dan sejarah. Gerakan ini sifatnya sangat khas secara politis antara lain bersifat konservatif, populer dan praktis. Keaktifan kaum fundamentalis di bidang politik dapat dilihat dari dua sebab yang melatarbelakanginya. Pertama, reaksi mereka terhadap perubahan (ancaman perubahan) yang mengancam identitas nasional. Misalnya reaksi gerakan muslim di Pakistan, kaum Sikh di Punjab, kelompok Free Presbyterians di Ulster (Irlandia Utara), gerakan Gush Emunim dan Haredi di Israel. Dan kedua, reaksi terhadap usaha-usaha pemerintah untuk memperluas bidang umum di suatu negara bangsa. Misalnya gerakan fundamentalisProtestan di Amerika, persudaraan muslim di Nigeria, aktivis Nakshibensi di Turki, gerakan Tajdid di Nigeria dan Revolusi Islam Iran yang terkenal itu.

Kedua, di bidang ekonomi kaum fundamentalis diarahkan pada upaya untuk memperbaiki kembali terhadap struktur sistem ekomomi berdasarkan nilai-nilai dan moral agama. Salah satu ciri khas faham ini ialah seringkali menentang keras sistem ekonomi sekuler, sosiolog Marxiz dan kapitalis yang melanda dunia. Oleh karena itu maka dikenal sistem ekonomi Kristen, sosialisme Budha dan perbankan Islam. Dari segi ini perekonomian gerakan ini sangat berbeda dengan sistem perekonomian pada umumnya. Misalnya, penghapusan riba dalam bank Islam, dan menekankan pembangunan tempat-tempat ibadah bagi umat Budha. Munculnya ekonomi 
fundamentalis disebabkan oleh reaksi atas ketidakadilan dan ketimpangan sistem ekonomi akibat transformasi dan revolusi industri serta informasi yang terjadi diberbagai belahan dunia. Tetapi perlu dicatat bahwa ekonomi fundamentalis tidak menentang ataupun menghalangi kemajuan dan kemakmuran di dunia ini dan bahkan berusaha menyelaraskan keseimbangan ekomomi duniawi dengan kepentingan ukhrowi.

Keliga, menyangkut militansi, dikemukakan bahwa kaum fundamentalis dalam upaya mewujudkan cita-citanya tidak jarang menempuh jalam kekerasan. Dari beberapa observasi, tingkat kekerasan yang telah terjadi di beberapa wilayah, disimpulkan tergantung dari tiga hal yaitu (1) ideologi dan persepsi dari suatu gerakan, serta kekuatan yang dimiliki, (2) sifat musuh dan ancamannya bagi suatu gerakan dan (3) sifat/ciri-ciri kepemimpinan dan organisasi suatu pergerakan.

Selanjutnya, dalam mengenali kaum fundamentalisme ini, aspek yang penting adalah "kemilitanan"nya. Ada empat pokok yang perlu dikemukakan dalam kaitannya dengan aspek ini, yaitu (1) konteks politik yang diperkirakan mendukung aksi kekerasan, (2) pengaruh kekerasan terhadap masyarakat, (3) implikasi intemasional dari aksi kekerasan, dan (4) kekerasan menurut masyarakat agamis.

Terakhir, Suprayogo kemukakan bahwa isi buku ini sangat penting digunakan untuk memahami fenomena keagamaan. Kaitannya dengan perkembangan dunia sekarang ini yang tampaknya agama semakin dijadikan pusat perhatian dunia, sehingga tidak sedikit orang menyebutnya sebagai abad kebangkitan agama, maka kajian-kajian dari berbagai aspek kehidupan seperti ekonomi, politik, hukum, sosial dan juga budaya sangat diperlukan. Walaupun buku ini hanya merupakan kumpulan tulisan dari beberapa ahli, ditulis secara singkat, maka membawa resiko tidak mampu menampilkan analisis dan juga data yang memadai. Akan tetapi, di balik sedikit kelemahan yang tidak mungkin dihindari itu, buku ini cukup memberikan informasi awal guna membuka kajian-kajian yang luas dan dalam berikutnya. Khusus bagi Suprayogo, buku ini tidak saja memberikan informasi tentang aktifitas politik elit agama di berbagai negara, melainkan juga memberikan banyak perspektif yang harus diperhatikan dalam mengembangkan kajian tentang kiai yang akan datang, baik dari aspek teoritik maupun metodologinya. 


\section{G. Kesimpulan}

Istilah "fundamentalisme", secara etimologi berasal dari kata "fundamen" yang berarti dasar. Sedangkan secara terminologi, fundamentalisme adalah aliran pemikian keagamaan yang cenderung menafsirkan teks-teks keagamaan secara kaku (rigid) dan literalis (textual).

Faham fundamentalis adalah sebagai gerakan yang berjuang untuk menegakkan kembali norma-nonma dan keyakinan agama tradisional dalam tatanan kehidupan bermasyarakat yang dianggap telah menyimpang karena faham sekularisme. Faham fundamentalis bisa lahir dari semua agama dan di mana saja, karena itu dikenal istilah Fundamentalis Islam, Hindu, Budha, Khatolik, Protestan dan juga Yahudi.

Pada urnumnya, Fundamentalisme bisadikaitkan dengan politik, restrukturisasi ekonomi, dan juga dengan hal-hal yang berhubungan dengan militansi. Hubungan antara faham fundamentalis dan politik, bersifat sangat komplek mengingat adanya perbedaan-perbedaan bentuk pemerintah, hubungan internasional, pengelolaan ekonomi, adat istiadat dan sejarah. Gerakan ini sifatnya sangat khas secara politis antara lain bersifat konservatif, populer dan praktis.

Dan di bidang ekonomi, kaum fundamentalis diarahkan pada upaya untuk memperbaiki kembali struktur sistem ekomomi berdasarkan nilai-nilai dan moral agama. Salah satu ciri khas faham ini ialah seringkali menentang keras sistem ekonomi sekuler. Namun, tidak menentang ataupun menghalangi kemajuan dan kemakmuran di dunia ini dan bahkan berusaha menyelaraskan keseimbangan ekomomi duniawi dengan kepentingan ukhrowi.

Sedangkan dalam hal militansi, kaum fundamentalis dalam upaya mewujudkan cita-citanya tidak jarang menempuh jalam kekerasan. Dari beberapa observasi, tingkat kekerasan yang telah terjadi di beberapa wilayah, disimpulkan tergantung dari tiga hal yaitu (1)ideologi dan persepsi dari suatu gerakan, serta kekuatan yang dimiliki, (2)sifat musuh dan ancamannya bagi suatu gerakan dan (3)sifat/ciri-ciri kepemimpinan dan organisasi suatu pergerakan.

Kaum fundamentalis Islam dapat digolongkan menjadi dua, yaitu Fundamentalis Sunni dan Fundamentalis Syi'ah. Pemimpin dari kelompok pertama biasanya berasal dari orang awam, berlatar belakang pendidikan universitas umum 
dan belajar agama secara otodidak. Biasanya mereka ini selalu beroposisi dengan para ulama dan mempunyai hubungan yang erat dengan penguasa yang sah. Sedangkan fundamentalis kelompok kedua, merupakan kebalikannya. Pergerakan kelompok ini selalu dalam satu komando dari apa yang dinamakan Mullah.

Dalam perspektif teori analisis diskursus (diskursus analysis) kemunculan sebuah institusi, praktik dan konsep sangat terkait dengan empat hal: will (keinginan), power (kakuasaan), discipline (disiplin) dan regime (pemerintahan). Empat hal ini dikenal dengan istilah formasi diskursif(discursive formations), bangunan yang mendasari adanya sebuah diskursus.

Dengan menggunakan pendekatan "keterpenggalan sejarah", bisa jadi gerakan fundamentalisme di Indonesia tidak memiliki keterkaitan dengan gerakan fundamentalisme di luar. Namun, adanya ide keterpenggalan sejarah itu tidak berarti meniadakan adanya relasi antar-diskursus.

\section{Endnotes}

Bassam Tibi, Ancaman Fundamentalisme Rajutan Islam Politik dan Kekacanan Dunia Baru. Ter. Imron Rosyidi, dkk (Jogjakarta: Tiara Wacana, 2000), x.

Di sini kita bisa melihat bahwa bagaimana keberhasilan Amerika menggunakan media international sebagai alat kampanye. Bahkan terkadang CNN menjadi lebih agresif dan provokatif dibandingkan dengan Amerika itu sendiri. Pada sisi ini, kita bisa melihat bahwa ternyata negara sebesar Amerika perlu memanfaatkan media untuk kepentingannya. Dalam kasus ini, BBC London sangat berbeda dengan CNN. Meskipun BBC adalah stasiun TV milik Inggris, dan Inggris sendiri juga mendukung kampanye perang terorismenya Amerika, namun pemberitaan BBC bisa menepiskan kepentingan negaranya.

Robert Audi, Ed, The Cambridge Dictionary of Philosophy (Melbourne: Cambridge University Press, 1999), 320-321. Michel Foucault (1926-1984), French philoshopher and historian of thought. Foucault's earlist writings (Mental Illness and Personality, 1954) focuse on psychology and developed within the frame works of Marxism and existential phenomenology. He soon moved beyond these frameworks, in directions suggested by two fundamental influences: history and philoshophy of science, as practiced by Bachelard and Canguilhem, and the modernist literature of Raymon Russel, Bataille, and Maurice Blanchot. In studies of psychiatry (History of Madness in the Classical Age, 1961), Clinical Medicine (The Birth of the Clinic, 1963), and the Social Sciences (The Order of Things, 1966), Foucault developed an approach to intellectual 
history, "the Archaeology of Knowledge", that treated system of thought as "discursive formations" independent of the beliefs and intentions of individual thinkers. Like Canguilhem's history of science and like modernist literature, Foucault's archaeology displated the human subject from the central role in played in the humanism dominant in our culture since Kant. He reflected on the historical and philosophical significance of his archaeological method in The Archaeology of Knowledge (1969).

4 H. L. Dreyfus dan Paul Rabinow, Michel Foucault: Beyond Structuralism and Hermeneutics (Hemeld Hempsted: Harvester Wheatsheaf, 1982), 44ff.

Jeremy R. Carrette,Foucault and Religion Spiritual Corporality and Political Spirituality (London and New York: Routledge, 2000), 11.

6 http://www.geocities.com/collegepark/6453/myth.html

Sheila McDonough, Muslim Ethicsand Modernity: A Comparative Study of the Ethical Thought of Sayyid Ahmad Khan and Mawlana Mawdudi (Canada: Canadian Corporation for Studies in Religion, 1984), 2.

Selain istilah fundamentalisme sebenarnya ada istilah lain yang hampir dekat yang digunakan oleh kalangan Islamisis untuk menunjukkan gejala radikalisme Islam, yakni neo- normativis.

9 Seyyed Vali Reza Nasr, Mawdudi and the Making of Islamics Revivalism (New YorkOxford: University Press, 1996), 4.

10 Muhammad Sa'id al-'Ashmawy, Islamic "Fundamentalism" Islamis Humanism, and Realtions with the West dalam Buku Against Islamic Extremism, Carolyn Fluerh-Lobban, Ed (Florida: University Press of Florida, 2001), 25. Al-'Ashmawy, like other writers today, does not use the term "fundamentalism" to describe what he thinks is better understood as extremism. The fundamentals of Islam (ushul al-din)- the Quran and Sunna and the practice of the Five Pillars - are not dispute. No one, liberal or conservative, is questioning the fundamentals of faith; matters of interpretation of the sources and application of these ideas in contemporary society are what are at issue.

1 Emmanuel Sivan, Radical Islam, Medieval Theology and Modern Politics (Yale University Press, Enlarged Edition, 1985), x.

12 Abdurrahman Kasdi, Fundamentalisme Jslam Timur Tengah: Akar Teologi, Kritik Wacana, dan Politisasi Agama dalam Jurnal Tashwirul Afkar (Jakarta: LAKPESDAM NU, No. 3 Tahun 2002), 20.

13 Istilah "Archaeology" ini dia pinjam dari Immanuel Kant sebagimana juga istilah geneology yang ia pinjam pula dari Nietzsche. Secara khusus Foucault menulis formasi teori ini dalam bukunya The Archaeology of Knowledge.

14 Carrete, Foucult, 11. Sebuah esei yang sangat terkenal ditulis Foucault mengenai hal ini adalah "What is an Author". Esai ini membahas tentang kematian pengarang 
sebagaimana esainya Roland Barthes "The Death of the Author", yang dimuat dalam Image, Muxic, Text, 1997. Kedua esai memiliki kecenderungan yang sama berbicara mengenai relasi pengarang dan yang dikarang.

15 Foucault, The Archaeology, 131.

16 Muhammad Sa'id al-Asymawi, Islam and the Political Order (Washington D.C: the Council for Research in Values and Philoshopy, 1994), 78.

17 Muhammad Mahaddesin, Islamic Fundamentalism: the New Global Threat (Washington D.C.: Seven Locks Press, 1993), 4.

18 Uraian mendalam mengenai the discontinuity of history Michel Foucalt bisa dilihat dalam bukunya The Archaeology of Knowledge \& the Discourse on Langrage, (New York: Pantheons Book, 1972), khususnya di bagian introduction, 3-17. Ia meyakini bahwa di balik ide "the continuity of history" sesungguhnya di sana ada "the discontimuity".

19 Syafiq Hisyam, Fundomentalisme Islam: Perebutan dan Pergeseran Makna dalam Jumal Tashwirul Afkar (Jakarta: LAKPESDAM NU, No. 3 Tahun 2002), 13-17

20 Abdu Hadi Abdul Rahman, Sullah al-Nash Qira 'ah fi Taudzif al-Nazh al-Dini (Beirut: al-Markaz al-Tsaqafi al-Arabi, 1993), 183.

21 Ibid., 183.

22 Syafiq Hisyam, Fundamentalisme Islam: Perebutan dan Pergeseran Makna dalam Jumal Tashwirul Afkar (Jakarta: LAKPESDAM NU, No. 3 Tahun 2002), 18.

23 Imam Suprayogo, Fundomentalis dan Kekerasan Beragama dalam Jumal STAIN Malang (Malang: STAIN Press, No. 4 Tahun 1997), 75-80. Fundamentalisme: Memahami Sebuah Fenomena Keagamaan dalam Buku Reformulasi Visi Pendidikan Islam (Malang: STAIN Press, 1999), 108-116. 


\section{Bibliography}

Al- 'Ashmawy, Muhammad Sa'id. Islamic "Fundamentalism" Islamis Humanism, and Realtions with the West dalam Buku Against Islamic Extremism, Carolyn Fluerh-Lobban, Ed. Florida: University Press of Florida, 2001. . Islam and the Political Order. Washington D.C: the Council for Research in Values and Philoshopy, 1994.

Arifin, Syamsul. Gerakan Sosial Islam: Studi Tentang Ideologi, Jaringan, dan Gerakan Sosial Kelompok Fundamentalis Agama di Kota Malang. Proposal Disertasi Program Doktor IAIN Sunan Ampel Surabaya, 2003.

Audi, Robert Ed. The Cambridge Dictionary of Philosophy. Melbourne: Cambridge University Press, 1999.

Budiman, Ajang. Fundamentalisme dan Kebudayaan dalam Kajian Pusat Studi Islam dan Filsafat (PSIK) UMM. Jum'at, 4 April 2003.

Carrette,Jeremy R. Foucault and Religion Spiritual Corporality and Political Spirituality: London and New York: Routledge, 2000.

Dreyfus, H.L. dan Paul Rabinow. Michel Foucault: Beyond Structuralism and Hermeneutics. Hemeld Hempsted: Harvester Wheatsheaf, 1982.

Foucault, Michel. The Archaeology of Knowledge \& the Discourse on Language. New York: Pantheons Book, 1972.

Fuad, Ahmad Nur. Fundamentalime, Pluralisme, dan Dialog Antar-Agama dalam Kajian Pusat Studi Islam dan Filsafat (PSIK) UMM. Jum'at, 9 Mei 2003.

Gordon, Scott. The History and Philosophy of Social Science. London: Routledge, 1991.

Hisyam, Syafiq. Fundamentalisme Islam: Perebutan dan Pergeseran Makna dalam Jurnal Tashwirul Afkar. Jakarta: LAKPESDAM NU, No. 3 Tahun 2002.

http://www.geocities.com/collegepark/6453/myth.html

Ishomuddin. Fundamentalisme Sebagai Fenomena Keagamaan dan Kebudayaan dalam Kajian Pusat Studi Islam dan Filsafat (PSIK) UMM. Jum'at, 11 April 2003. 
Kasdi, Abdurrahman. Fundamentalisme Islam Timur Tengah: Akar Teologi, Kritik Wacana, dan Politisasi Agama dalam Jurnal Tashwirul Afkar. Jakarta: LAKPESDAM NU, No. 3 Tahun 2002.

Mahaddesin, Muhammad. Islamic Fundamentalism: the New Global Threat. Washington D.C.: Seven Locks Press, 1993.

McDonough, Sheila. Muslim Ethics and Modernity: A Comparative Study of the Ethical Thought of Sayyid Ahmad Khan and Mawlana Mawdudi. Canada: Canadian Corporation for Studies in Religion, 1984.

Nasr, Seyyed Vali Reza. Mawdudi and the Making of Islamics Reviralism. New York-Oxford: University Press, 1996.

Nurhakim, Muhammad. Meneguhkan Kembali Gagasan Pluralisme dalam Agama dalam Kajian Pusat Studi Islam dan Filsafat (PSIK) UMM. Jurn'at, 9 Mei 2003.

Rahman, Abdul Hadi Abdul. Sultah al-Nash Qira'ah fi Taudzif al-Nazh alDini. Beirut: al-Markaz al-Tsaqafi al-Arabi, 1993.

Sivan, Emmanuel. Radical Islam, Medieval Theology and Modern Politics. Yale University Press, Enlarged Edition, 1985.

Suprayogo, Imam. Fundamentalis dan Kekerasan Beragama dalam Jurnal STAIN Malang. Malang: STAIN Press, No. 4 Tahun 1997.

Tibi, Bassam. Ancaman Fundamentalisme Rajutan Islam Politik dan Kekacauan Dunia Baru. Ter. Imron Rosyidi, dkk Jogjakarta: Tiara Wacana, 2000. 